\title{
Natural compounds obtained from plants as alternatives for meat and meat products preservation
}

\author{
Compostos naturais obtidlos de plantas como alternativas para a conservação de carne e produtos \\ cárneos \\ Compuestos naturales obtenidos de plantas como alternativas para la conservación de carnes y \\ productos derivados
}

Yasmim Gonçalves Lacerda

ORCID: https://orcid.org/0000-0001-8288-9904 Universidade José do Rosário Vellano, Brazil

E-mail: yasmimlacerda@hotmail.com

Jussani da Silva Paulino

ORCID: https://orcid.org/0000-0001-6688-9613 Universidade José do Rosário Vellano, Brazil

E-mail: paulino.jussani@gmail.com

Gabriella Fuzari Esteves

ORCID: https://orcid.org/0000-0001-7506-0567 Universidade José do Rosário Vellano, Brazil E-mail: gabriella.f.esteves@gmail.com

Roberto da Costa Esteves Júnior

ORCID: https://orcid.org/0000-0003-1257-2818

Universidade José do Rosário Vellano, Brazil E-mail: robertoestevesjr@gmail.com

Bruno César Góes

ORCID: https://orcid.org/0000-0002-4409-1720 Universidade José do Rosário Vellano, Brazil E-mail: bruno.goes@unifenas.br

Édina de Fátima Aguiar

ORCID: https://orcid.org/0000-0002-7883-5628 Universidade José do Rosário Vellano, Brazil E-mail: edina.aguiar@unifenas.br

Bruno Cesar Corrêa Salles

ORCID: https://orcid.org/0000-0002-4444-9673

Universidade José do Rosário Vellano, Brazil E-mail bruno.alfenas@hotmail.com

Valéria Quintana Cavicchioli

ORCID: https://orcid.org/0000-0001-5565-507X

Universidade José do Rosário Vellano, Brazil

E-mail: valeria_cavicchioli@hotmail.com

\begin{abstract}
The purpose of this review is to demonstrate the findings on the use of natural compounds as preservatives in meat and meat products as a healthier and safer alternative compared to the use of synthetic preservatives. Due to its biological composition, meat and its derivatives are susceptible to spoilage, a process that can be delayed with the use of synthetic food preservatives. However, it is known that some products can trigger undesirable effects on consumer health. In recent years, there has been a greater demand for products obtained naturally or directly from a biological organism without laboratory interference in their composition, in order to reduce risks to the consumer. The most promising compounds belong to the groups of phenolic and flavonoid compounds, which have a proven, positive effect on oxidation and microbial development. Findings on the use of natural compounds as preservatives in meat and meat products demonstrate an alternative to increased shelf life without risking consumer health.
\end{abstract}

Keywords: Antimicrobial compounds; Natural antioxidants; Plant extracts; Preservatives.

\section{Resumo}

O objetivo desta revisão é demonstrar os achados sobre o uso de compostos naturais como conservantes em carnes e produtos cárneos como uma alternativa mais saudável e segura em comparação ao uso de conservantes sintéticos. Devido à sua composição biológica, a carne e seus derivados são suscetíveis à deterioração, processo que pode ser retardado com o uso de conservantes alimentares sintéticos. No entanto, sabe-se que alguns produtos podem desencadear 
efeitos indesejáveis à saúde do consumidor. Nos últimos anos, tem havido uma maior demanda por produtos obtidos naturalmente ou diretamente de um organismo biológico sem interferência em sua composição, a fim de reduzir os riscos ao consumidor. Os compostos mais promissores pertencem aos grupos dos compostos fenólicos e flavonóides, que têm efeito comprovado e positivo na redução de processos oxidativos e de deterioração microbiana. Descobertas sobre o uso de compostos naturais como conservantes em carnes e produtos cárneos demonstram uma alternativa para aumentar a vida útil sem colocar em risco a saúde do consumidor.

Palavras-chave: Compostos antimicrobianos; Antioxidantes naturais; Extratos de plantas; Conservantes.

\section{Resumen}

El propósito de esta revisión es demostrar los hallazgos sobre el uso de compuestos naturales como conservantes en la carne y los productos cárnicos como una alternativa más saludable y segura al uso de conservantes sintéticos. Debido a su composición biológica, la carne y sus derivados son susceptibles al deterioro, proceso que puede retrasarse con el uso de conservantes sintéticos para alimentos. Sin embargo, se sabe que algunos productos pueden desencadenar efectos indeseables en la salud del consumidor. En los últimos años ha habido una mayor demanda de productos obtenidos de forma natural o directa de un organismo biológico sin interferencia de laboratorio en su composición, con el fin de reducir los riesgos para el consumidor. Los compuestos más prometedores pertenecen a los grupos de compuestos fenólicos y flavonoides, que tienen un efecto probado y positivo sobre la oxidación y el desarrollo microbiano. Los descubrimientos sobre el uso de compuestos naturales como conservantes en la carne y los productos cárnicos demuestran una alternativa para aumentar la vida útil sin poner en peligro la salud del consumidor.

Palabras clave: Compuestos antimicrobianos; Antioxidantes naturales; Extractos de plantas; Conservantes.

\section{Introduction}

Meat production is one of the main agricultural activities in the world, involving numerous domestic species (Pighin et al., 2016). According to the Organization for Economic Cooperation and Development - OECD / Food and Agriculture Organization of the United Nations - FAO (2018), there is an estimation of an annual increase in meat production of 48 million tons by 2027, reaching up to 367 million tons. Still, there is an expectation that by 2027 there will be a $15 \%$ increase in global consumption and $3 \%$ in per capita consumption (OECD/FAO (2018). Such demand is related to population growth and also to the high energy and nutritional density of meat, which has macro and micronutrients that are indispensable for the maintenance of human health (Burin et al., 2016).

Due to their composition, meat and meat products are susceptible to deterioration, especially caused by microbial development and lipid oxidation (Schaich, 2017; Yazgan et al., 2020). Therefore, several factors have been identified contributing to the deterioration, designated as intrinsic and extrinsic factors. The nutrients and favorable $\mathrm{pH}$, in addition to the absence of natural antimicrobial factors can be observed (Anas et al., 2019). The extrinsic factors are those related to the environment and conditions to which the meat is subjected. Variations in temperature, handling and storage conditions are examples of these factors (Anas et al., 2019). In order to control these factors to optimize the shelf life of meat products and to minimize deterioration processes, the use of preservative compounds has been studied over the years (Alirezalu et al., 2020).

Synthetic preservatives such as sodium metabisulfite, butyl hydroxyanisol (BHA), butyl hydroxytoluene (BHT) and sodium nitrite (Paschoal et al., 2019; Beya et al., 2021) have long been employed in the food industry, with the aim of optimizing the shelf life of meat products (Quadros et al., 2020). However, several studies have pointed out that the use of synthetic preservatives may promote undesirable effects on the human organism due to the toxicity of such compounds (Liu \& Mabury, 2020). For this reason, consumers are increasingly aware and demanding natural and minimally processed products, leading food market and industry to seek alternatives in this sense. Likewise, researchers have explored the use of natural compounds, derived mainly from plants, with antioxidant and antimicrobial characteristics as alternatives for the conservation of meat products (Pateiro et al., 2018).

The antioxidant and antimicrobial capacities of a natural product are related to the high content of phenolic compounds, represented by phenolic acids, flavonoids, anthocyanins and tannins. In this sense, some products derived from plants have shown promising results in preventing or delaying deterioration in meat products, such as rosemary (Rosmarinus officinalis), red 
fruit species (Arctostaphylos sp., Vaccinium sp., Rubus sp., Ribes nigrum, Rubus chamaemorus, Fragaria ananassa, Vitis sp.), mustard (Brassica juncea), oregano (Origanum vulgare), sage (Salvia officinalis), lotus (Nelumbo nucifera), curry (Murraya koenigii L), green tea (Cammelia sinensis), cinnamon sticks (Cinnamomum zeylanicum B), ginger (Zingiber officinale), among others (Kumar et al., 2015; Aziz \& Karboune, 2018; Lorenzo et al., 2018). Considering that compounds with bioactive metabolites are generally considered safe, the use of these compounds has been extensively explored by researchers (Beya et al., 2021). Thus, the purpose of this review is to present the main processes responsible for the deterioration of meat and meat products and to demonstrate the findings on the use of natural plant compounds as preservatives in meat and meat products as a healthier and safe alternative to the use of synthetic preservatives.

Use the paragraph as a template (TNR font 10 - justified - space 1,5).

\section{Meat composition and the deterioration process}

Meat has nutrients of fundamental importance to the maintenance of human health, and this is due to its contents being rich in proteins, fatty acids, vitamins and minerals (Burin et al., 2016).

The most abundant nutrient in meat is water, which directly influences its quality, as it is related to its texture, color and flavor (Ribeiro et al., 2019). Meat proteins have a high biological value because they are easily digestible, in addition to providing eight essential amino acids not synthesized by the human organism (Wood, 2017). Meat is also a source of fatty acids such as unconjugated linoleic acid (CLA) (Pighin et al., 2016), which has been identified as an important ally in the prevention and treatment of metabolic diseases such as obesity, cancer, diabetes and cardiovascular diseases (Fuke \& Nornberg, 2017). In addition to conferring nutritional attributes, fatty acids are also involved in the sensory characteristics of meat affecting its juiciness and tenderness, but despite of this, this nutrient can serve as a substrate to trigger lipoperoxidation (Pighin et al., 2016; Ribeiro et al., 2019). B-complex vitamins are essential to human health as they act as cofactors or precursors in enzyme systems. Vitamin B12 is necessary for the synthesis of neurotransmitters and DNA, and the only natural sources of B12 vitamin are meat and animal origin products (Wood, 2017).

Nutritional features depend on several factors such as genetics, feeding and handling of the animals, in addition to postmortem processes that occur during the conversion of the muscle into meat. Due to its complex nutritional composition, fresh meat is a product highly susceptible to deterioration (Pighin et al., 2016). Proteins, polyunsaturated fatty acids, high water activity and favorable $\mathrm{pH}$ are examples of factors that trigger oxidative and microbial processes (Anas et al., 2019; Yazgan et al., 2020).

Deterioration stems from a combination of physical, chemical, biochemical and microbiological processes, resulting in the degradation of important nutrients and sensory changes. Additionally, the safety of the product for consumption may be compromised, due to the possibility of developing pathogenic microorganisms and the production of toxic compounds (Jackson \& Penumetcha, 2019; Huang \& Ahn, 2019; Campêlo et al., 2019).

\subsection{Lipid oxidation}

Lipid oxidation is a factor that limits the quality and acceptability of meat and derivatives, as it triggers color changes, unpleasant flavors and produces substances with great potential for toxicity (Ribeiro et al., 2019).

Animal origin products have large amounts of polyunsaturated fatty acids, making them prone to oxidation (Schaich, 2017; Yazgan et al., 2020). Lipids can undergo auto-oxidation, enzymatic oxidation and photo-oxidation through complex reactions. In meat and meat products, auto-oxidation is the main process, which involves the stages of initiation, propagation and termination (Figure 1) (Domínguez et al., 2019).

Initiation is a controversial and poorly defined process, although some reactions are consensus among researchers. It is known that an oxygen molecule $\left(\mathrm{O}_{2}\right)$ and a fatty acid do not react spontaneously with each other, as they have different states of rotation 
(Berdahl et al., 2010). Therefore, oxygen must be activated, resulting in singlet oxygen $\left({ }^{1} \mathrm{O}_{2}\right)$, a biologically relevant reactive species, hydrogen peroxide $\left(\mathrm{H}_{2} \mathrm{O}_{2}\right)$, superoxide anion $\left(\mathrm{O}_{2} \bullet-\right)$ or hydroxyl radical $(\mathrm{OH} \bullet)$. The formation of these free radicals occurs through reactions of hydrogen abstraction mediated by metallic ions, light, radiation or other means. From this, the formation of an intermediate compound occurs, which consists of a free, highly reactive lipid radical. When other $\mathrm{O}_{2}$ molecules are present, hydroperoxyl radicals are formed. These radicals have the ability to extract a hydrogen molecule from a lipid, which generates another carbon-centered radical, initiating the propagation phase (Berdahl et al., 2010; Domínguez et al., 2019; Di Mascio et al., 2019).

Figure 1 - Overview of the different stages of lipid oxidation.

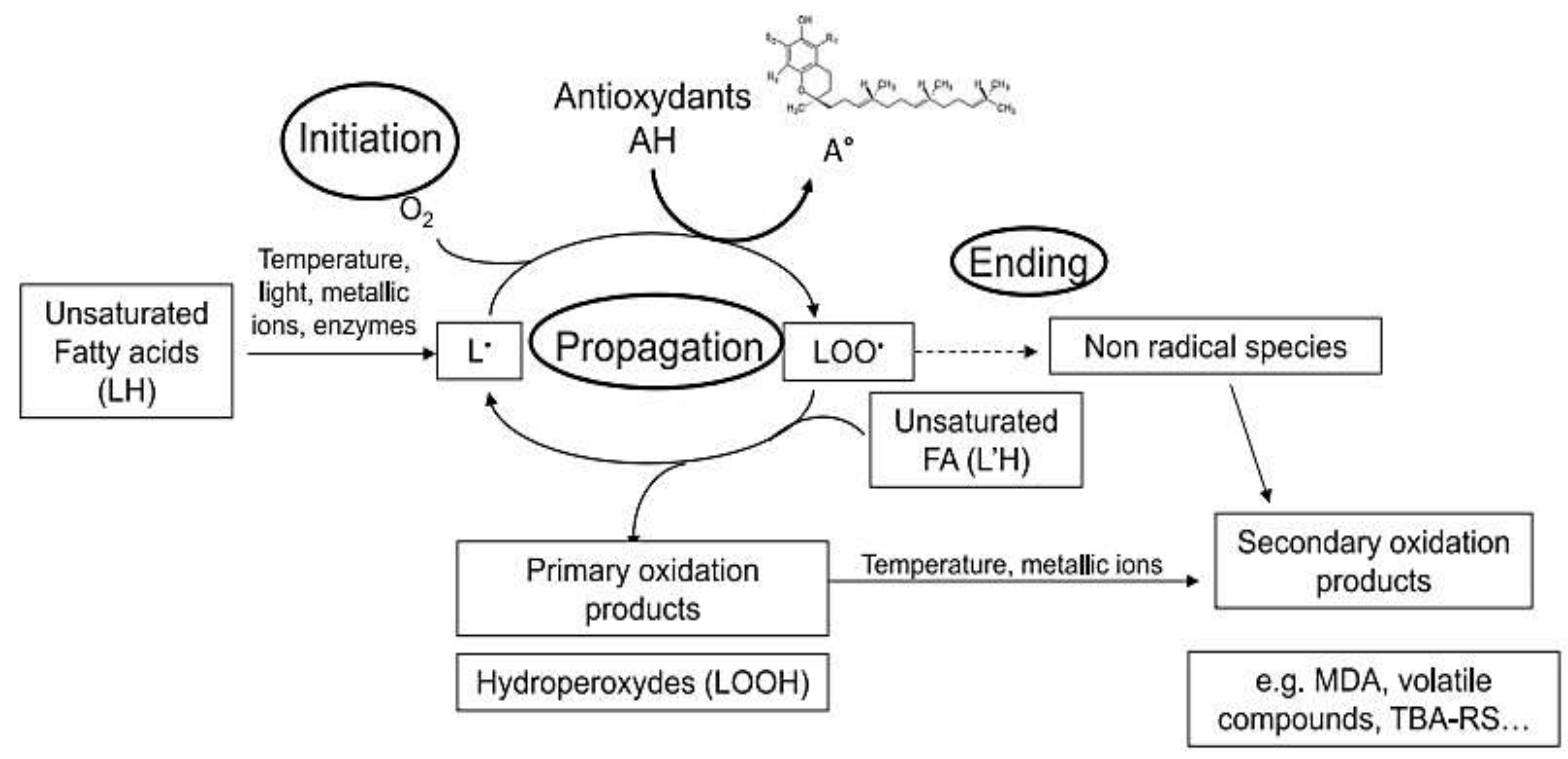

Source: Guyon et al. (2016).

In propagation, a reaction results in the conversion of the hydroperoxyl radical to hydroperoxide. This radical is easily decomposed at high temperatures or in the presence of metals, producing byproducts such as aldehydes, short-chain hydrocarbons, alcohols, esters, acids and ketones. Thusly, the release of disgusting and rancid aromas occurs. The alkoxy and hydroxyl radicals can continue the propagation phase by extracting a hydrogen from a lipid and forming another carbon-centered radical (Berdahl et al., 2010; Hematyar et al., 2019).

The last phase of lipid oxidation corresponds to its termination. In this phase, two radicals react with each other and after that, the formation of stable products occurs through the action of antioxidants. However, this action is not always efficient and capable of containing the radicals generated in the oxidation process, which can lead to the formation of new reactive compounds (Hematyar et al., 2019; Domínguez et al., 2019).

Lipid oxidation is a major cause of rejection and drop in product quality (Campêlo et al., 2019). In addition to the altered sensory aspect, toxic compounds can be formed during this process, such as $\alpha$ and $\beta$-unsaturated carbonyl compounds, acrolein, crotonaldehyde, 4-hydroxy-trans-2-nonenal and 4-hydroxy-trans-2-hexenal, malonaldehyde and cholesterol, associated with the development of inflammatory diseases, cancer, atherosclerosis and early aging (Vieira et al., 2017).

In addition to the changes that occur naturally between the compounds, some steps involved in meat processing can cause the formation of oxidizing species (Dantas et al., 2015). Cutting, mixing, grinding, meat filling in casings, heat treatment, salting and curing, smoking, fermentation and drying also produce a large number of oxidizing species (Dantas et al., 2015). The packaging conditions of the meat can also be crucial to the lipid oxidation process. When packaged in the presence of oxygen, 
there is a greater formation of oxidizing species, which reduces its shelf life (Duran \& Kahye, 2020).

Excessive amounts of oxidizing species are related to various diseases such as Alzeheimer, Parkinson's, atherosclerosis, diabetes, autism, heart failure, chronic fatigue, fatty liver, chronic fatigue syndrome, obesity and depression, reinforcing the need to contain the oxidation process (Jackson \& Penumetcha, 2019; Huang \& Ahn, 2019).

\subsection{Oxidation of proteins and pigments}

Meat and meat products are rich in proteins (Guyon et al., 2016). This nutrient is responsible for meat texture, water retention and color (Bao \& Ertbjerg, 2019). The component responsible for meat pigment is a water-soluble protein called myoglobin, which can also be found in the form of oxymyoglobin or metmyoglobin (Ribeiro et al., 2016).

Just like lipid oxidation, the oxidation of meat proteins depends on several factors, such as the type of muscle that it originates from, processing, as well as intrinsic and extrinsic factors (Guyon et al., 2016). Thus, the oxidation of proteins can be triggered by oxidative modification of an amino acid, by cleavage of the peptide mediated by free radicals and by the formation of the cross-linked protein, due to the reaction with lipid peroxidation products (Ribeiro et al., 2019).

The oxidation of proteins does not only cause damage to texture and color. There is a decrease in digestibility and nutritional losses of essential amino acids profile (Guyon et al., 2016). The amino acids most prone to undergo oxidation are cysteine, tyrosine, tryptophan, histidine, proline, arginine, lysine, methionine and phenylalanine, depending on their positions within the peptide chain (Guyon et al., 2016; Jongberg et al., 2017).

During the oxidation process, several changes occur, including the cleavage of peptide bonds, modification of amino acid side chains and formation of derivatives of covalent intermolecular reticular proteins (Jongberg et al., 2017). The reaction products are usually protein hydroperoxides and carbonyl groups, and crosslinking depends on the formation of disulfide and dithyrosine between neighboring peptide chains (Jongberg et al., 2017). Such products may contain reactive groups that contribute to damaging the membrane and many cellular functions (Ribeiro et al., 2019).

Pigment oxidation occurs through changes in the iron ion present in myoglobin. Under normal conditions, the meat has a purple-red color, however, when exposed to high concentrations of oxygen, the iron ion $\left(\mathrm{Fe}^{2+}\right)$ is reduced, changing the color to bright red, due to the conversion of myoglobin to oxymyoglobin (Ribeiro et al., 2019). On the other hand, when the meat is exposed to low oxygen concentrations, the $\mathrm{Fe}^{2+}$ ion is deoxygenated and there is a transformation into deoxymyoglobin. This form is unstable and triggers an oxidation reaction when it comes in contact with oxygen again, which results in metmyoglobin, turning the meat brown, due to the presentation of iron in its oxidized form $\left(\mathrm{Fe}^{3+}\right)$ (Ribeiro et al., 2019).

\subsection{Microbial deterioration}

Microbial deterioration of meat leads to losses in quality due to changes in organoleptic features, reducing the shelf life. Microbial contamination can also offer a risk to consumer health, which is a major concern for the food industry and food safety authorities (Campêlo et al., 2019).

Since it is a food of high biological value due to its composition rich in proteins, essential amino acids, B vitamins and minerals such as iron, magnesium and zinc, meat and meat products are an excellent source for development of bacteria, fungi and yeasts. In aerobic conditions, some deteriorating microorganisms can develop, leading to adverse changes in sensory characteristics, such as appearance, odor, texture and taste (Anas et al., 2019).

Pathogenic bacteria are the most important group of microorganisms that cause the deterioration of meat products. Inappropriate handling after slaughter, contamination by gastrointestinal content, contamination of surfaces and utensils and even the lack of hygiene of the slaughterhouse employees, can contribute to the transfer of microorganisms that lead to bacterial deterioration of the meat (Sohaib et al., 2016). The investigation of contaminant microorganisms in the meat due to failure in 
slaughter procedure has been carried out with the objective of verifying the sanitary hygienic control of the slaughterhouses (Gabaron et al., 2020). When assessing the presence of contamination-indicating microorganisms in carcasses of colonial chickens and verifying the possible points of contamination during the stages of the slaughter process, Gabaron et al. (2020) did not identify the presence of Salmonella spp (Gabaron et al., 2020). Regarding Escherichia coli, coagulase negative Staphylococcus and Klebsiella spp. the authors observed counts within the limit established by current legislation (Gabaron et al, 2020). Likewise, Santos and Ferreira (2017) carried out a microbiological assessment of environmental air, utensils, handling surfaces and the hands of handlers in a pig slaughterhouse (Barbieri et al., 2019). The authors observed the presence of aerobic mesophiles and enterobacteria in ambient air samples and on handling surfaces, suggesting the possibility of crosscontamination, and the presence of enterobacteria on the hands of the handlers (Santos \& Ferreira, 2017).

The deboning process exposes meat to the environment, equipment and utensils, thus facilitating cross-contamination by pathogenic microorganisms (Voloski et al., 2016). On the meat surface, the bacteria most commonly found on the meat surface are Escherichia coli, Salmonella spp., Staphylococcus epidermidis, and Bacillus cereus (Sohaib et al., 2016).

Another procedure related to the microbial deterioration process is the packaging. When done in the presence of oxygen, the growth and biochemical activity of aerobic microorganisms occurs (Voloski et al., 2016). However, it is worth mentioning that microbial deterioration can be triggered under different conditions of handling and storage, by different types of bacteria (Anas et al., 2019). In aerobic conditions and temperatures from 1 to $25^{\circ} \mathrm{C}$, there is a stimulus for the growth of Pseudomonas spp., Acinetobacter spp., Moraxella spp. Brochothrix, Flavobacterium, lactic acid bacteria, Micrococcus, Psychrobacter, Pseudomonas, Staphylococcus and several genera of the Enterobacteriaceae family (Sohaib et al., 2016; Ghabraie et al., 2016; Anas et al., 2019). Lactic acid bacteria (LAB) depend on pH, water activity, $\mathrm{O}_{2}$ and carbon dioxide $\left(\mathrm{CO}_{2}\right)$ to develop $(\mathrm{Anas}$ et al., 2019). They are mainly represented by heterofermentative species of mesophilic lactobacilli such as Lactobacillus casei spp., L. paracasei spp., L. rhamnosus spp. and L. plantarum spp. Pediococcus spp., Leuconostoc spp. and Micrococcus spp (Barbieri et al., 2019; Pereira et al., 2020). In addition to sensory changes in meat, these bacteria are considered the main producers of biogenic amines (BA), compounds originated from the decarboxylation of amino acids through microbial activities. It is also known that BA can cause toxic effects in humans, with symptoms as headache, heart palpitations, vomiting, diarrhea, depending on individual sensitivity (Barbieri et al., 2019), evidencing the importance of controlling the development of LAB in meat products.

Another group of microorganisms that may be present in meat are fungi. These are found in low proportions in meat and meat products, as they have less ability to compete for nutrients, compared to bacteria (Sohaib et al., 2016). According to Sohaib et al. (2016), the main yeasts isolated from the meat surface are Candida mesenterica, Candida saitoana, Cryptococcus albidus, Cryptococcus laurentii, Cryptococcus luteolus, Rhodotorula glutinoso and Rhodotorula mucilaginosa (Sohaib et al., 2016). Despite the difficulty of competing for nutrients, some species of fungi have been associated with meat deterioration, especially species capable to grow in the temperature range of -10 to $-2{ }^{\circ} \mathrm{C}$, water activity of 0.80 and wide $\mathrm{pH}$ range, such as Acremonium, Alternaria, Aspergillus, Cladosporium, Epicoccum and Penicillium (Sohaib et al., 2016). Black spots on the product surface are characteristic of the so-called "black mold" and are more commonly caused by Cladosporium cladosporioides, Cladosporium herbarum and Penicillium hirsutum (Sohaib et al., 2016).

\section{Synthetic Preservatives in Meat and Meat Products}

The use of preservatives is a strategy used by food industry to increase the shelf life of food, containing the deterioration process (Ribeiro et al., 2019). They are usually synthetic additives that promote technological functions and should be used taking into account the maximum permitted levels and conditions established by the FAO / WHO Committee of Specialists in Food Additives, by the Food Chemicals Code or by the European Union, as specified in Brazilian regulation (Brasil, 2019). 
Sodium metabisulfite (MBS), butyl hydroxyanisol (BHA), butyl hydroxytoluene (BHT) and sodium nitrite are the main preservatives used by the food industry to obtain a longer shelf life of products (Paschoal et al., 2019, Beya et al., 2021).

Although the use of preservatives is effective to extend shelf-life of meat and meat products, its application has been questioned, due to possible toxicity associated to this compounds (Pateiro et al., 2018). Undesirable effects also include DNA damages and mutations, elevation in blood lipids and cholesterol levels and formation of potentially mutagenic nitrosamines. Such reactions can lead to the development of cancer, hives, rhinitis, changes in vision and respiratory problems (Ribeiro et al., 2019).

MBS is an additive used mainly for its antimicrobial action and has been strongly related to damage to the cardiovascular system (Natskoulis et al., 2018; Noorafshan et al., 2014). Noorafshan et al. (2014) carried out a study to evaluate the effects of MBS on the cardiovascular system of rats for an eight-week period. The authors observed a $20 \%$ reduction in the total volume of ventricular tissue in animals treated with MBS compared to the control treatment $(\mathrm{P}<0.02)$. Capillary volume and length were reduced by $43 \%$ on average in rats treated with MBS compared to animals that received control treatment $(\mathrm{P}<0.02)(\mathrm{Noorafshan}$ et al., 2014). Cytotoxicity of MBS has also been reported. Yoo et al. (2018) during an in vitro assay, with human A549 alveolar epithelial cells incubated with MSB at a concentration of 50 to $500 \mu \mathrm{g} / \mathrm{ml}$, isolated and associated with propylene glycol (PG) at a concentration of 31.25 to $1000 \mu \mathrm{g} / \mathrm{ml}$. The authors also carried out an in vitro test with rats exposed to the inhalation of these compounds. The cytotoxicity and subacute inhalation toxicity of each chemical and its mixtures were evaluated. It was observed that MBS above $100 \mu \mathrm{g} / \mathrm{mL}$ induced significant cytotoxicity and when associated with PG, the cytotoxicity of the mixture was increased. Inhalation of MBS and PG caused specific clinical signs, including nasal sounds, sneezing and eye irritation, which were not found in the single exposure of MS. Total protein concentration and lactate dehydrogenase activity in broncho alveolar lavage increased. Adverse effects were observed in the nasal cavity, with squamous cell metaplasia identified in front of the nasal cavity in all high-exposure groups, which completely recovered 7 days after the end of the exposure, demonstrating the toxicity of the interaction of the compounds (Yoo et al., 2018).

The assessment of the toxic effects of BHA has shown to be related to hormonal and neurological changes (Liu \& Mabury, 2020). Kang et al. (2005), when evaluating BHA's estrogenic and androgenic activity, administering it to immature rats aged 20 days for three consecutive days, observed a reduction in the absolute and relative weights of the uterus (Kang et al., 2005). Park et al. (2019) conducted an in vitro study with human astrocyte cells incubated in the presence of BHA $100 \mathrm{uL}$ for 48 hours (Park et al., 2019). The authors observed a cytotoxic effect of astrocytes by promoting the accumulation of cytosolic calcium and the stress of the endoplasmic reticulum in the cells (Park et al., 2019).

The toxic effects of BHT are also frequently studied (Liu \& Maburi, 2020). An in vitro study with Ishikawa cells demonstrated that BHT can suppress the basal expression of estrogen-responsive genes (Alofe et al., 2019). Another study developed from a diet containing $0.05 \%$ or $0.5 \%$ BHT offered to $\mathrm{C} 3 \mathrm{H}$ mice over 10 months, promoted the development of liver tumors (Witschi, 1986).

The toxicity of sodium nitrite was demonstrated in a study developed by Özen et al. (2014), who evaluated the effects of the preservative by administering it to Swiss mice daily for 8 months (Özen et al., 2014). The authors observed histopathological changes, damage to nitrosative tissue and lipid peroxidation in the liver and kidneys, in addition to inducing chromosomal aberrations (Özen et al., 2014).

Considering these findings, there is a significant interest in natural additives as an alternative for the preservation of meat and meat products (Lorenzo et al., 2018). 


\section{Natural Compounds with Preservative Properties}

Natural preservatives are defined as products obtained directly from a biological organism without laboratory interference in their composition (Campêlo et al., 2019). They are a source of bioactive compounds that can act in the prevention of the deterioration process of meat and meat products, safely preserving its sensory and nutritional features (Aminzare et al., 2019).

In this context, plants have been used as a raw material for obtaining preservatives, due to their composition rich in metabolites that promote antioxidant and antimicrobial effects. In addition, compounds obtained from plants are considered nutritionally safe and easily degraded (Mostafa et al., 2018). For its use in food, plants must go through an extraction process, due to the large amount and diversity of metabolites presented (Panja, 2018).

The classification of natural compounds obtained from plants depends on the part of the plant used (Table 1).

Table 1. Classification of natural compounds obtained by plants.

\begin{tabular}{|c|c|c|c|}
\hline Type of product & Definition & Examples of products & Conventional methods of use \\
\hline Herbs & $\begin{array}{l}\text { Originating from the leaves of } \\
\text { plants. }\end{array}$ & $\begin{array}{c}\text { Rosemary, oregano, basil, } \\
\text { coriander, bay leaf, marjoram. }\end{array}$ & $\begin{array}{l}\text { Spices, teas, cosmetics and } \\
\text { herbal medicines }\end{array}$ \\
\hline Spices & $\begin{array}{l}\text { Originating from different parts } \\
\text { of the plants (fruits, seeds, bark, } \\
\text { roots and shoots). }\end{array}$ & $\begin{array}{c}\text { Cinnamon, pomegranate, thyme, } \\
\text { cloves, nutmeg. }\end{array}$ & $\begin{array}{c}\text { Spices, teas, cosmetics and } \\
\text { herbal medicines }\end{array}$ \\
\hline Essential oils & $\begin{array}{l}\text { Substances produced through the } \\
\text { secondary metabolism of plants. }\end{array}$ & $\begin{array}{l}\text { Essential oil of coriander seeds, } \\
\text { thyme, cloves (sprouts), sage, } \\
\text { rosemary, oregano, cinnamon, } \\
\text { coriander. }\end{array}$ & Herbal cosmetics and medicines \\
\hline
\end{tabular}

Source: Adapted from Campêlo et al. (2019).

Herbs refer to the leaves of plants, whereas spices are characterized as a product of different parts of the plant, with the exception of leaves. Essential oils are derived from aromatic plants that have bioactive compounds normally produced by the secondary metabolism of plants, produced by all parts of the plant and stored in cells, cavities, channels and trichomes (Campêlo et al., 2019).

Traditional methods for extracting compounds from herbs and spices are infusion, decoction, maceration, percolation, reflux extraction and Soxhlet extraction (Panja, 2018). There are also advanced methods such as extraction of pressurized liquids, extraction of supercritical fluid, extraction assisted by microwave, extraction assisted by ultrasound, extraction assisted by enzymes and extraction of pulsed electric field (Panja, 2018). Different solvents can be used in the extraction process, such as acetone, methanol, pure ethanol, 70, 80, and 90\% ethanol, dimethyl sulfoxide and distilled or deionized water (Aminzare et al., 2019).

For essential oils, vaporization and hydrodistillation are the most used methods for commercial extraction, however new technologies have been studied, among them ultrasound-assisted extraction, ohmic-assisted extraction, pulsed electric field extraction and micro-assisted extraction. waves. These techniques can be combined with each other to obtain essential oils in a more ecological way, reducing the extraction time (Roohinejad et al., 2017). 


\subsection{Antioxidant and antimicrobial capacity of a natural preservative}

The antioxidant capacity of natural preservatives is related to their content in phenolic compounds, mainly phenolic acids, phenolic diterpenes, flavonoids and volatile oils (Aminzare et al., 2019). Some phenolic compounds can prevent the production of free radicals and the spread of oxidizing species, while eliminating other free radicals and chelate prooxidants (transition metals). The redistribution of the reaction potential within an antioxidant molecule is related to the phenol ring with resonant double bonds in its structure (Figure 2), which redistributes the reaction potential. This potential in oxidizing species is very high, but when transferred to an antioxidant, its level drops in large proportions, thus interrupting the self-oxidation process (Kumar et al., 2015; Huang \& Ahn, 2019). While phenolic acids capture free radicals, flavonoids eliminate free radicals and chelated metals $\left(\mathrm{Fe}^{2+}, \mathrm{Fe}^{3+}\right.$ and $\left.\mathrm{Cu}^{2+}\right)$, influencing the antioxidant potential of the compounds according to their structure and pattern of functional groups (Kumar et al., 2015).

The mechanism of antimicrobial action of natural extracts and essential oils does not seem to be fully understood, however, substances contained in these products can affect microbial cells by different mechanisms (Aziz \& Karboune, 2018). The hydrophobicity of the compounds present in natural extracts is one of the most important factors, as it allows them to cross the cell wall and the cytoplasmic membrane of microorganisms, breaking the structure of their different layers of polysaccharides, fatty acids and phospholipids, causing the permeabilization of membrane and its electrochemical disturbance (Hassoun \& Coban, 2017). Another proposed mechanism is the effect on the phospholipid bilayer of the cell membrane, when there is the inhibition of enzymatic systems that are responsible for the regulation of energy and synthesis of structural compounds of bacteria, compromising their genetic material and resulting in the formation of fatty acid hydroperoxides (Calo et al., 2015; Aziz \& Karboune, 2018; Pateiro et al., 2018).

Figure 2 - Synthetic and natural antioxidants with at least one phenol ring with a -OH group in bond, necessary for the stabilization of free radicals.

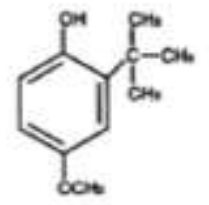

BHA *

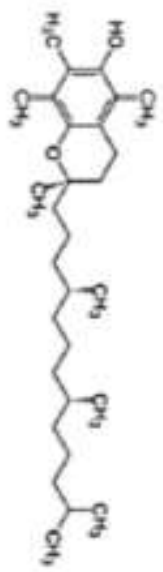

Tocopherol

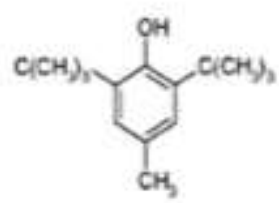

BHT *<smiles>O=C1CC(C2CCC(O)CC2)OC2CC(O)C[C@H](O)[C@H]12</smiles>

Flavone

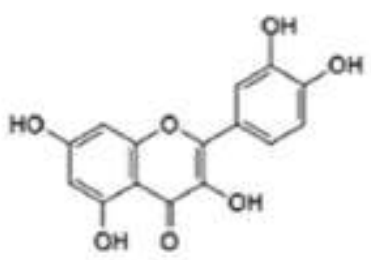

Quercetin

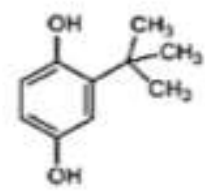

TBH *<smiles>CCCOC(=O)c1cc(O)c(O)c(O)c1</smiles>

PG*<smiles>O=c1c(-c2ccc(O)cc2)coc2cc(O)ccc12</smiles>

Diadzcin<smiles>O=c1c(-c2ccc(O)cc2)coc2cc(O)cc(O)c12</smiles>

Genistein

Isoflavon

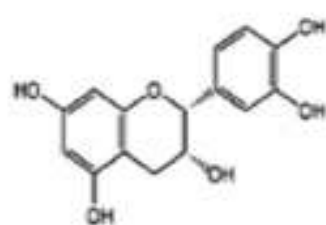

Epicatechin<smiles>O=C(O)c1cc(O)c(O)c(O)c1</smiles>

Gallic acid

BHA*: Hydroxyanisol butylate; BHT*: Hydroxytoluene butylate; TBH* Terc-Butyl hydroperoxide; PG*: Propyl Gallate. Source: Huang and Ahn (2019). 


\subsection{Natural compounds in the preservation of meat and meat products}

Natural products have been used for many years as teas, spices and foods, due to the presence of compounds with therapeutic effects, such as antioxidants, antimicrobial, antifungal, antitumor and anti-inflammatory drugs (Aminzare et al., 2019). The use of bioactive compounds extracted from plants, whether essential oils and/or aqueous, alcoholic or hydroalcoholic extracts, isolated or applied together with coating films, becomes of interest to delay the deterioration of meat and meat products because they represent alternatives for the use of synthetic preservatives (Table 2) (Lachno et al., 2019).

\subsubsection{Essential oils as preservatives in meat and meat products}

Essential oils are compounds found in plants, acting in important biological functions such as those related to the defense mechanism in microorganisms, insects and animals (Reis et al., 2020). Due to their rich composition in bioactive compounds, capable of triggering a preservative action, essential oils have been used for several decades by the pharmaceutical and cosmetic industry (Reis et al., 2020). Currently, its application has been explored in the conservation of meat products.

Table 2 - Main natural compounds obtained from plants for preservation of food products.

\begin{tabular}{|c|c|c|c|}
\hline Plant & Special metabolite & Mechanism of action & Reference \\
\hline Camellia sinensis & $\begin{array}{c}\text { Polyphenols and catechins } \\
\text { (galocatechin, epicatechin, } \\
\text { epigallocatechin, epicatechin and } \\
\text { epigallocatechin gallate) }\end{array}$ & Antioxidant and antimicrobial & Shah et al., 2018 \\
\hline Rosmarinus officinalis & $\begin{array}{c}\text { Carnosic acid, carnosol and } \\
\text { rosmanol }\end{array}$ & Antioxidant & Vergara et al., 2021 \\
\hline Curcuma longa & $\begin{array}{l}\text { Polyphenols, flavonoids, tannins } \\
\text { and ascorbic acid }\end{array}$ & $\begin{array}{l}\text { Antioxidant, antimicrobial and } \\
\text { antifungal }\end{array}$ & Hu et al., 2017 \\
\hline Zingiber officinale & $\begin{array}{c}\text { Curcumin, zingerone, shogaol and } \\
\text { gingerol }\end{array}$ & Antioxidant and antimicrobial & Hamad et al., 2016 \\
\hline $\begin{array}{l}\text { Cinnamomum } \\
\text { zeylanicum }\end{array}$ & Polyphenols & Antioxidant and antibacterial & Raeisi et al., 2019 \\
\hline Origanum vulgare & $\begin{array}{c}\text { Carvacrol, thymol, p-cymene and } \\
\gamma \gamma \text {-terpenene }\end{array}$ & $\begin{array}{l}\text { Antioxidant, antibacterial and } \\
\text { anti-inflammatory }\end{array}$ & Cui et al., 2019 \\
\hline
\end{tabular}

Source: Authors.

There is a great diversity of plants regarding their preservative action on meat and meat products. Among the main species, rosemary (Rosmarinus officinalis), is a plant with recognized antioxidant and antimicrobial action (Aziz \& Karboune, 
2018). Rosemary essential oil has bioactive compounds in its composition such as monoterpene hydrocarbons (camphene, verbenene, $\alpha$-pinene, $\beta$-pinene, limonene), oxygenated monoterpenes (1,8-cineole, linalool, camphor, borneol, verbenone) and sesquiterpenes ( $\beta$-caryophyllene), associated with its preservative effects (Jafari-Sales \& Pashazadeh, 2020). Sirocchi et al. (2017) investigated the effect of rosemary essential oil combined with modified atmosphere conditions on beef stored under refrigeration. Based on microbiological data, the authors were able to observe a delay in the deterioration process, which ex tended the shelf life of beef by approximately 10 days under storage conditions with a high level of O2 at $4^{\circ} \mathrm{C}$. Similarly, Badia et al. (2020) evaluated the effects of using rosemary and oregano essential oils on the development of LAB in vacuum-packed sausages stored under refrigeration conditions. The authors observed that all treatments delayed the development of LAB and obtained empirical models that relate the shelf life of the sausage and the growth rate of LAB with the concentration of essential oils, opening the premise for further studies to assess the influence of essential oils on the shelf life of different meat industry products. No sensory changes related to the addition of essential fundamentals were observed. (Sirocchi et al., 2017; Badia et al., 2020).

The oregano essential oil has polyphenols, carvacrol, thymol, p-cymene and $\gamma$-terpenene in its composition, giving this product characteristics related to the control of the oxidation reaction and microbial growth, which justifies its possible application as a food preservative (Cui et al., 2019; Ulusoy et al., 2018). Ulusoy et al. (2018) evaluated the preservative effect of oregano essential oil on cured, salted and dried goat meat samarella, a typical food from Cyprus. It was possible to observe a delay in microbial development in the samples with the addition of $5 \%$ of oregano essential oil after the traditional drying method, under the exposure of solar radiation (Ulusoy et al., 2018). Al-Hijazeen et al. (2018), demonstrated the preservative effect of oregano essential oil in association with tannic acid, when added in different concentrations to chicken meat subsequently cooked and stored under refrigeration. The authors observed that the concentrations of $200 \mathrm{ppm}$ of oregano essential oil together with $10 \mathrm{ppm}$ of tannic acid presented a delay in the oxidation process and smaller alterations in the sensory characteristics of the chicken meat (Al-Hijazeen et al., 2018). Thus, it was possible to verify that the essential oil of oregano is a promising product for application as a natural preservative for the meat industry (Ulusoy et al., 2018; Al-Hijazeen et al., 2018).

Ginger (Zingiber officinale) contains up to $3 \%$ of essential oil and is composed of curcumin, zingerone, shogaol and gingerol, which provides a spicy flavor and therapeutic effect, the latter obtaining antimicrobial and antioxidant action (Saranya et al., 2016, Rashid et al., 2017). Studies still claim proteolytic action, which can give meat tenderness (Rashid et al., 2017). Considering chicken meat in their study, Hamad et al. (2016) added different levels of ginger essential oil and evaluated the microbiological characteristics of chilled meat (Hamad et al., 2016). The authors observed that the samples containing ginger oil at concentrations of 1250 and $6250 \mu \mathrm{g} / \mathrm{mL}$, showed lower microbial development at $5 \pm 2{ }^{\circ} \mathrm{C}$ during 15 days of storage, demonstrating the preservative effect of this natural product. Sensory changes in odor were observed in samples treated with ginger essential oil, which presented an odor suggestive of the spice (Hamad et al., 2016). Hartanti et al. (2018) evaluated the preservative effects of ginger essential oil alone or in association with lemon grass essential oil in chicken meat stored under refrigeration conditions. In this study, the association of oils was more efficient in delaying microbial development than the application of isolated oils. The authors found that chicken meat samples containing concentrations of $0.2 \%$ ginger essential oil $+2 \%$ lemongrass essential oil had an extended shelf life of 9 days, stored at $2-7^{\circ} \mathrm{C}$ (Hartanti et al., 2018).

Cinnamon (Cinnamomum zeylanicum) has polyphenols, such as vanillic, caffeic, gallic, protocatechoic, p-oceanic and ferulic acid in its composition, which confer antioxidant and antibacterial action to the plant. This justifies its application as a natural preservative in food products (Raeisi et al., 2019). Lyu et al., (2017) in order to demonstrate the effectiveness of using cinnamon essential oil as a natural preservative, evaluated the effects of gamma radiation combined with the product on the quality of Northern Snakehead fish fillets (Channa argus). The authors noted that microbial growth was retarded with increased radiation doses and cinnamon oil concentration. It was also possible to observe the same trend in relation to the increase in the radiation dose and concentration of cinnamon oil in the delay of the meat oxidation process during 8 days of storage at $4^{\circ} \mathrm{C}(\mathrm{Lyu}$ 
et al., 2017). Similarly, Raeisi et al. (2019) observed the effect of cinnamon essential oil and rosemary essential oil by incorporating both at a concentration of $5 \mathrm{mg} / \mathrm{ml}$, in edible coatings of alginate for chicken meat (Raeisi et al., 2019). Treatments were applied alone or in associations. The combination of oils delayed the oxidation process of chicken meat during storage for 15 days under refrigerated conditions, demonstrating a great potential of the products as natural preservatives to increase the shelf life of chicken meat. In sensory evaluations, it was observed that the addition of essential oils improved the aroma of the samples and delayed the unpleasant odor resulting from the oxidation process during the storage period (Raeisi et al., 2019).

\subsubsection{Vegetable extracts as preservatives in meat and meat products}

Natural bioactive compounds can also be found in vegetable herbs and spices or even in their residues, which after the extraction process, have a known antioxidant and antimicrobial action (Munekata et al., 2020). Thus, the application of plant extracts in food preservation has been explored. In this context, plant extracts have been used in several meat products without generating losses in quality and increasing the shelf life of the products (Ribeiro et al., 2019).

As already mentioned, rosemary (Rosmarinus officinalis) is one of the most studied plants regarding its antioxidant and antimicrobial action in foods (Aziz \& Karboune, 2018). In addition to essential oils, its extract could also be explored for its preservative potential in meat and meat products (Pires et al., 2017; Alves et al., 2020). Pires et al. (2017) evaluated the storage capacity of chicken meat hamburgers with the addition of rosemary and green tea extracts in comparison with the synthetic antioxidant BHA (Pires et al., 2017). The addition of natural antioxidants did not affect the physicochemical and color parameters of chicken burgers. After 120 days at $-18^{\circ} \mathrm{C}$, the sample containing $480 \mathrm{mg}$ of rosemary extract $/ \mathrm{kg}$ remained without signs of oxidative rancidity. The result was statistically similar to the sample containing $20 \mathrm{mg} \mathrm{BHA} / \mathrm{kg}$, suggesting that rosemary extract can be used as a natural preservative to replace BHA (Pires et al., 2017). Several other studies were carried out using rosemary extract, alone or in combination, as a meat preservative and its derivatives. Considering fish meat in their study, Alves et al. (2020) evaluated different natural antioxidants. Rosemary extract, oregano extract and basil extract at concentrations of $10 \%$ in brine were added to evaluate the conservation capacity of tilapia fillets. The authors observed that the samples containing the addition of extracts maintained their quality for 21 days, while the control treatment already showed signs of oxidative rancidity during this time (Alves et al., 2020).

Green tea (Camellia sinensis) is a plant that has an abundant amount of phenolic compounds, with known antioxidant and antimicrobial activities. Its technological application in food has shown promising results (Aziz \& Karboune, 2018; Lorenzo $\&$ Munekata, 2016). In a study evaluating the antimicrobial potential of green tea in duck meat preservation, Suradi et al. (2019) observed that the $5 \%$ concentration of green tea showed better conservation in the face of microbial deterioration, maintaining the physicochemical characteristics of duck meat, with the exception of color (Suradi et al., 2019). Mosavinezhad et al. (2020) also found the preservative effects of green tea, considering chicken meat, by observing that the samples treated with Camelia sinensis at $0.5 \%$ had better physicochemical parameters, less evidence of oxidative rancidity, microbial deterioration and sensory alterations, demonstrating that the application of green tea extract as a preservative in duck and chicken meat can be efficient (Mosavinezhad et al., 2020).

Turmeric is a spice derived from the rhizome of the Curcuma longa plant, which has about 235 chemical and bioactive constituents, mainly represented by phenolic and terpenoid compounds, such as polyphenols, flavonoids, tannins and ascorbic acid, which give the product antioxidant, antimicrobial and antifungal properties (Tanvir et al., 2017;.Hu et al., 2017). In a study evaluating the effect of turmeric extract as a natural preservative in fresh lamb sausage, packaged in modified atmosphere with fat replacement during storage at $2^{\circ} \mathrm{C}$, Carvalho et al. (2020) observed an improvement in the antioxidant capacity of lamb sausages, with a delay in the lipid oxidation process and generation of related volatile compounds, without great influence on the physicochemical characteristics, except for a yellowish color. Thus, they were able to demonstrate that the use of turmeric 
extract can be a strategy to increase the shelf life of lamb sausages (Carvalho et al., 2020). Bojorges et al. (2020), also with the objective of evaluating the use of turmeric extract as a food preservative, developed an alginate coating with the addition of the extract as an active ingredient and applied it to pork loin, beef loin and chicken breast meats stored at $4^{\circ} \mathrm{C}$. It was possible to observe an important antioxidant effect during storage, with change only in the color in the physicochemical characteristics. Thus, they could observe that the addition of turmeric extract as an active ingredient in an edible alginate coating can be a good alternative for meat preservation (Bojorges et al., 2020). Aulia et al. (2019) demonstrated the effectiveness of turmeric by adding its extract, at a concentration of 5\%, to the meat of Lalawak fish (Barbodes balleroides), obtaining a lesser total bacterial count of the product during 6 days of storage. This suggests that turmeric extract at $5 \%$ concentration has the ability to retard bacterial growth in fish meat (Aulia et al., 2019). Similarly, Arshad et al. (2019) demonstrated the effectiveness of turmeric by using the spice powder together with the application of gamma irradiation (2 kGy) on chicken meat (Arshad et al., 2019). The authors did not detect total bacterial and coliform colony forming units in the groups treated with turmeric and gamma radiation for 14 days. The treatment with only turmeric powder showed an antioxidant effect during the storage period. Thus, it was possible to verify that the use of spice powder can also trigger a preservative effect during the storage of chicken meat (Arshad et al., 2019).

Ginger extract (Zingiber officinale) is rich in pungent compounds and has shown positive effects created by agents such as antineoplastic, antispasmodic and antiemetic agents, enzyme inhibitors, anti-hemorrhagic agents, antifungal agents, neural cell protectors, antirheumatics, microbicides, anti-inflammatory and antioxidants (Sousa et al., 2013). In addition to the aforementioned preservative effects of ginger essential oil, the use of the plant extract as a food preservative was also studied. Considering the use of meat from cull chickens for the production of sausages, added with ginger extract, Reshi et al. (2017) observed an improvement in physicochemical and microbiological quality, with acceptable changes in sensory characteristics, during 15 days of storage at $4^{\circ} \mathrm{C}$, considering that the use of ginger extract can be an alternative for the conservation of sausages made from chicken meat. Similarly, Draszanowska et al. (2020) evaluated the use of ginger when comparing the addition of its rhizome in a formula containing $1 \%$ water and $1.5 \%$ of peeled and grated rhizome with the addition of sodium ascorbate, a synthetic preservative used by the food industry in canned pork meat (Draszanownska et al., 2020). It was observed that during days 0,20 and 40, there was a similar antioxidant effect between the samples with the addition of ginger rhizome and the samples with the addition of sodium ascorbate, demonstrating that the application of ginger as a preservative for canned pork meat can be promising (Draszanownska et al., 2020).

\section{Final Considerations}

Oxidation processes and microbial development are the main factors that influence the deterioration of meat and its products. The use of compounds obtained from plants for the preservation of these products has been a thoroughly researched option in relation to synthetic products, due to the lower risk of toxicity and damage to consumers' health.

Several studies have shown promising results in the use of compost extracted from herbs and spices, especially essential oils. These products can be good substitutes for synthetic preservatives due to their compositions rich in metabolites with antioxidant and antimicrobial characteristics, in addition to their history of effectiveness when applied in meat products technology. Therefore, one can consider a tendency to increase the consumption of meat and meat products with natural preservatives, as they are safer and more efficient to contain the deterioration process.

\section{Acknowledgments}

The authors gratefully acknowledge University José do Rosário Vellano and thank the financial support of the present study through National Council for the Improvement of Higher Education (CAPES), process 88882.365352 / $2019-01$ and the Brazilian National Research Council (CNPq). 


\section{References}

Al-Hijazeen, M., Mendonca, A., Lee, E. J., \& Ahn, D. U. (2018). Effect of oregano oil and tannic acid combinations on the quality and sensory characteristics of cooked chicken meat. Poult. Sci. J., 97(2), 676-683.

Alirezalu, K., Pateiro, M., Yaghoubi, M., Alirezalu, A., Peighambardoust, S. H., \& Lorenzo, J. M. (2020). Phytochemical constituents, advanced extraction technologies and techno-functional properties of selected Mediterranean plants for use in meat products. A comprehensive review. Trends Food Sci Technol, $100,292-306$

Alofe, O., Kisanga, E., Inayat-Hussain, S. H., Fukumura, M., Garcia-Milian, R., Perera, L., Vasiliou, V., Whirledge, S. (2019). Determining the endocrine disruption potential of industrial chemicals using an integrative approach: Public databases, in vitro exposure, and modeling receptor interactions. Environ. Int., $131,104969$.

Alves, L. F. S., Corrêa, S. S., Rocha, J. D. A. M., Amado, D. A. V., Cottica, S. M., \& Souza, M. L. R. (2020). Use of natural antioxidants in sous vide tilapia fillet. Bol Ind Anim, 77, 1-12.

Aminzare, M., Hashemi, M., Ansarian, E., Bimakr, M., Hassanzad Azar, H., Mehrasbi, M. R., ... \& Afshari, A. (2019). Using natural antioxidants in meat and meat products as preservatives: A review. Adv Anim Vet Sci, 7(5), 417-426.

Anas, M., Ahmad, S., \& Malik, A. (2019). Microbial Escalation in Meat and Meat Products and Its Consequences. In Health and Safety Aspects of Food Processing Technologies (pp. 29-49). Springer, Cham.

Arshad, M. S., Amjad, Z., Yasin, M., Saeed, F., Imran, A., Sohaib, M., ... \& Hussain, S. (2019). Quality and stability evaluation of chicken meat treated with gamma irradiation and turmeric powder. Int. J. Food Prop., 22(1), 154-172.

Aulia, S., Rostini, I., Junianto, J., \& Pratama, R. I. (2019). Additions of extract turmeric on the presto of Lalawak fish (Barbodes balleroides) stored at room temperature. World Sci. News, 134(2), 63-73.

Aziz, M., \& Karboune, S. (2018). Natural antimicrobial/antioxidant agents in meat and poultry products as well as fruits and vegetables: A review. Crit. Rev. Food Sci. Nutr., 58(3), 486-511.

Badia, V., de Oliveira, M. S. R., Polmann, G., Milkievicz, T., Galvão, A. C., \& da Silva Robazza, W. (2020). Effect of the addition of antimicrobial oregano (Origanum vulgare) and rosemary (Rosmarinus officinalis) essential oils on lactic acid bacteria growth in refrigerated vacuum-packed Tuscan sausage. Brazilian Journal of Microbiology, 51(1), 289-301.

Bao, Y., \& Ertbjerg, P. (2019). Effects of protein oxidation on the texture and water-holding of meat: a review. Crit. Rev. Food Sci. Nutr., 59(22), 3564-3578.

Barbieri, F., Montanari, C., Gardini, F., \& Tabanelli, G. (2019). Biogenic amine production by lactic acid bacteria: A review. Foods, 8(1), 17.

Berdahl, D. R., Nahas, R. I., \& Barren, J. P. (2010). Synthetic and natural antioxidant additives in food stabilization: current applications and future research. In Oxidation in foods and beverages and antioxidant applications (pp. 272-320). Woodhead Publishing.

Beya, M. M., Netzel, M. E., Sultanbawa, Y., Smyth, H., \& Hoffman, L. C. (2021). Plant-Based Phenolic Molecules as Natural Preservatives in Comminuted Meats: A Review. Antioxidants, 10(2), 263.

Bojorges, H., Ríos-Corripio, M. A., Hernández-Cázares, A. S., Hidalgo-Contreras, J. V., \& Contreras-Oliva, A. (2020). Effect of the application of an edible film with turmeric (Curcuma longa L.) on the oxidative stability of meat. Food Science \& Nutrition, 8(8), 4308-4319.

Brasil. Ministério da Saúde/Agência Nacional de Vigilância Sanitária/Diretoria Colegiada (2019). Resolução da diretoria colegiada $n^{\circ}$ 272, de 14 de março de 2019.

Burin, P. C., de Souza Fuzikawa, I. H., Souza, K. A., Fernandes, A. R. M., Tonissi, R. H., \& de Goes, B. (2016). Características nutracêuticas da carne e sua importância na alimentação humana. Redvet, 17(12), 1-15.

Calo, J. R., Crandall, P. G., O'Bryan, C. A.; Ricke, S. C. (2015). Essential oils as antimicrobials in food systems-A review. Food control, 54, $111-119$.

Campêlo, M. C. S., Medeiros, J. M. S., \& Silva, J. B. A. (2019). Natural products in food preservation. Int. Food Res. J., 26(1).

Carvalho, F. A. L., Munekata, P. E., de Oliveira, A. L., Pateiro, M., Domínguez, R., Trindade, M. A., \& Lorenzo, J. M. (2020). Turmeric (Curcuma longa L.) extract on oxidative stability, physicochemical and sensory properties of fresh lamb sausage with fat replacement by tiger nut (Cyperus esculentus L.) oil. Food Research International, 136, 109487.

Cui, H., Zhang, C., Li, C., \& Lin, L. (2019). Antibacterial mechanism of oregano essential oil. Ind Crops Prod, 139, 111498.

Dantas, N. M., Sampaio, G. R., Ferreira, F. S., Labre, T. D. S., Torres, E. A. F. D. S., \& Saldanha, T. (2015). Cholesterol oxidation in fish and fish products. J. Food Sci., 80(12), R2627-R2639.

Di Mascio, P., Martinez, G. R., Miyamoto, S., Ronsein, G. E., Medeiros, M. H., \& Cadet, J. (2019). Singlet molecular oxygen reactions with nucleic acids, lipids, and proteins. Chem. Rev., 119(3), 2043-2086.

Domínguez, R., Pateiro, M., Gagaoua, M., Barba, F. J., Zhang, W., \& Lorenzo, J. M. (2019). A comprehensive review on lipid oxidation in meat and meat products. Antioxidants, 8(10), 429.

Draszanowska, A., Karpińska-Tymoszczyk, M., \& Olszewska, M. A. (2020). The effect of ginger rhizome and refrigerated storage time on the quality of pasteurized canned meat. Food Sci Technol Int, 26(4), 300-310. 
Duran, A., \& Kahve, H. I. (2020). The effect of chitosan coating and vacuum packaging on the microbiological and chemical properties of beef. Meat sci., 162, 107961.

Fuke, G., \& Nornberg, J. L. (2017). Systematic evaluation on the effectiveness of conjugated linoleic acid in human health. Crit. Rev. Food Sci. Nutr., 57(1), 17.

Gabaron, D. A., Otutumi, L. K., Borges, J. L., dos Santos Silva, V., de Almada, A. F. B., \& Júnior, R. P. (2020). Micro-organismos indicadores de contaminação de um abatedouro de frangos coloniais situado na região noroeste do estado do Paraná. Braz. J. Dev., 6(8), 60998-61007.

Ghabraie, M., Vu, K. D., Tata, L., Salmieri, S., \& Lacroix, M. (2016). Antimicrobial effect of essential oils in combinations against five bacteria and their effect on sensorial quality of ground meat. $L W T, 66,332-339$.

Guyon, C., Meynier, A., \& de Lamballerie, M. (2016). Protein and lipid oxidation in meat: A review with emphasis on high-pressure treatments. Trends Food Sci. Technol., 50, 131-143.

Hamad, A., Mentari, M., Djalil, A. D., \& Hartanti, D. (2016). Chemical Constituents of Ginger (Zingiber officinale Roscoe) Essential Oil and Its Potency as Natural Preservative on Fresh Chicken Meat. In Innovation of food technology to improve food security and health, 51.

Hartanti, D., Haqqi, M. Z. U., \& Hamad, A. (2018). Potency of combination of essential oils of ginger and lemongrass as fresh chicken meat natural preservative. Advanced Science Letters, 24(1), 91-94.

Hassoun, A., Coban, Ö. E. (2017). Essential oils for antimicrobial and antioxidant applications in fish and other seafood products. Trends Food Sci. Technol., $68,26-36$.

Hematyar, N., Rustad, T., Sampels, S., \& Kastrup Dalsgaard, T. (2019). Relationship between lipid and protein oxidation in fish. Aquac. Res, 50(5), $1393-1403$.

Hu, Y., Zhang, J., Kong, W., Zhao, G., \& Yang, M. (2017). Mechanisms of antifungal and anti-aflatoxigenic properties of essential oil derived from turmeric (Curcuma longa L.) on Aspergillus flavus. Food chem., 220, 1-8.

Huang, X., \& Ahn, D. U. (2019). Lipid oxidation and its implications to meat quality and human health. Food Sci. Biotechnol., 28(5), 1275-1285.

Jackson, V., \& Penumetcha, M. (2019). Dietary oxidised lipids, health consequences and novel food technologies that thwart food lipid oxidation: an update. Int. J. Food Sci. Technol, 54(6), 1981-1988.

Jafari-Sales, A., \& Pashazadeh, M. (2020). Study of chemical composition and antimicrobial properties of Rosemary (Rosmarinus officinalis) essential oil on Staphylococcus aureus and Escherichia coli in vitro. International Journal of Life Sciences and Biotechnology, 3(1), 62-69.

Jongberg, S., Lund, M. N., \& Skibsted, L. H. (2017). Protein oxidation in meat and meat products. Challenges for antioxidative protection. In Global food security and wellness (pp. 315-337). Springer, New York, NY.

Kang, H. G., Jeong, S. H., Cho, J. H., Kim, D. G., Park, J. M., Cho, M. H. (2005). Evaluation of estrogenic and androgenic activity of butylated hydroxyanisole in immature female and castrated rats. Toxicology, $213(1), 147-156$.

Kumar, Y., Yadav, D. N., Ahmad, T., \& Narsaiah, K. (2015). Recent trends in the use of natural antioxidants for meat and meat products. Compr Rev Food Sci F., 14(6), 796-812.

Lachno, A. S., Dutra, R., Severo, J., dos Santos Oliveira, M., \& de Oliveira, L. R. C. (2019). Bioaditivos e aditivos naturais em alimentos: Corantes, antioxidantes e aromatizantes. Bol Tec-Cient, 5(2).

Liu, R., \& Mabury, S. A. (2020). Synthetic Phenolic Antioxidants: A Review of Environmental Occurrence, Fate, Human Exposure, and Toxicity. Environ. Sci. Technol., 54(19), 11706-11719.

Lorenzo, J. M., \& Munekata, P. E. S. (2016). Phenolic compounds of green tea: Health benefits and technological application in food. Asian Pac J Trop Biomed. 6(8), 709-719.

Lorenzo, J. M., Pateiro, M., Domínguez, R., Barba, F. J., Putnik, P., Kovačević, D. B., ... \& Franco, D. (2018). Berries extracts as natural antioxidants in meat products: A review. Food Res Int, 106, 1095-1104.

Lyu, F., Zhang, J., Wei, Q., Gao, F., Ding, Y., \& Liu, S. (2017). Gamma radiation combined with cinnamon oil to maintain fish quality. Radiat. Phys. Chem., $141,220-222$.

Mosavinezhad, K., Shakerian, A., Sharafati Chaleshtori, R., \& Rahimi, E. (2020). Antimicrobial and Antioxidant Effects of Thymus daenensis and Camellia sinensis Ethanolic Extracts of Chicken Meat During Frozen Storage. Journal of Medicinal plants and By-product, 9(Special), 17-27.

Mostafa, A. A., Al-Askar, A. A., Almaary, K. S., Dawoud, T. M., Sholkamy, E. N., \& Bakri, M. M. (2018). Antimicrobial activity of some plant extracts against bacterial strains causing food poisoning diseases. Saudi J. Biol. Sci, 25(2), 361-366.

Munekata, P. E. S., Rocchetti, G., Pateiro, M., Lucini, L., Domínguez, R., \& Lorenzo, J. M. (2020). Addition of plant extracts to meat and meat products to extend shelf-life and health-promoting attributes: An overview. Current Opinion in Food Science, 31, 81-87.

Natskoulis, P. I., Lappa, I. K., \& Panagou, E. Z. (2018). Evaluating the efficacy of turbimetric measurements as a rapid screening technique to assess fungal susceptibility to antimicrobial compounds as exemplified by the use of sodium metabisulfite. Food Res Int, 106, $1037-1041$.

Noorafshan, A., Asadi-Golshan, R., Monjezi, S., \& Karbalay-Doust, S. (2014). Sodium metabisulphite, a preservative agent, decreases the heart capillary volume and length, and curcumin, the main component of Curcuma longa, cannot protect it. Folia biol., 60(6), 275. 
OECD/FAO (2018), OECD-FAO Agricultural Outlook 2018-2027, OECD Publishing, Paris/Food and Agriculture Organization of the United Nations, Rome.

Özen, H., Kamber, U., Karaman, M., Gül, S., Atakişi, E., Özcan, K., \& Atakişi, O. (2014). Histopathologic, biochemical and genotoxic investigations on chronic sodium nitrite toxicity in mice. Exp. Toxicol. Pathol., 66(8), 367-375.

Panja, P. (2018). Green extraction methods of food polyphenols from vegetable materials. Curr. Opin. Food Sci., 23, $173-182$.

Park, S., Lee, J. Y., Lim, W., You, S., \& Song, G. (2019). Butylated hydroxyanisole exerts neurotoxic effects by promoting cytosolic calcium accumulation and endoplasmic reticulum stress in astrocytes. J. Agric. Food Chem, 67(34), 9618-9629.

Paschoal, E. C., Beltrami, J. M., dos Santos, I. C., de Melo Germano, R., Soares, A. A., Dias, J. C. P., ... \& Otutumi, L. K. (2019). Estabilidade oxidativa da carne e derivados cárneos com o uso de antioxidantes naturais ou sintéticos em artigos publicados na base de dados da Scielo: revisão de literatura. Med Vet (UFRPE), 13(1), 136-142.

Pateiro, M., Barba, F. J., Domínguez, R., Sant'Ana, A. S., Khaneghah, A. M., Gavahian, M., ... \& Lorenzo, J. M. (2018). Essential oils as natural additives to prevent oxidation reactions in meat and meat products: A review. Food Res Int, 113, 156-166.

Pereira, M. T., dos Santos, J. S., \& de Santana, E. H. W. (2020). Importância das Bactérias Ácido Láticas e não Starter (NSLAB) na Tecnologia de Produção dos Derivados Lácteos. Ens Ciênc C Biol Agr Saúde, 24(4), 348-352.

Pighin, D., Pazos, A., Chamorro, V., Paschetta, F., Cunzolo, S., Godoy, F., ... \& Grigioni, G. (2016). A contribution of beef to human health: a review of the role of the animal production systems. Sci. World J, 2016.

Pires, M. A., Munekata, P. E., Villanueva, N. D., Tonin, F. G., Baldin, J. C., Rocha, Y. J., ... \& Trindade, M. A. (2017). The antioxidant capacity of rosemary and green tea extracts to replace the carcinogenic antioxidant (BHA) in chicken burgers. J. Food Qual., 2017.

Quadros, C. C., Lima, K. O., Latorres, J. M., Rocha, M., \& Prentice, C. (2020). Aplicação de hidrolisado proteico proveniente de tambaqui (Colossoma macropomum) como antioxidante natural na conservação de carne bovina moída. Chemistry, 168, 662-667.

Raeisi, M., Hashami, M., Afshari, A., Tabarraei, A., Aminzare, M., \& Jannat, B. (2019). Cinnamon and Rosemary Essential Oils Incorporated into Alginate Coating Improve Chemical and Sensorial Quality of Chicken Meat. Iran. J. Chem. Chem. Eng., 38(5), $293-304$.

Rashid, F., Dhanapal, K., Sravani, K., \& Saba, K. (2017). Potato and ginger peels: A potential new source of natural antioxidants. MOJ Food Process. Technol., 4, $1-5$.

Reis, J. B., de Figueiredo, L. A., Castorani, G. M., \& Veiga, S. M. O. M. (2020). Avaliação da atividade antimicrobiana dos óleos essenciais contra patógenos alimentares. Brazilian Journal of Health Review, 3(1), 342-363.

Ribeiro, J. S., Santos, M. J. M. C., Silva, L. K. R., Pereira, L. C. L., Santos, I. A., da Silva Lannes, S. C., \& da Silva, M. V. (2019). Natural antioxidants used in meat products: A brief review. Meat sci., 148, 181-188.

Roohinejad, S., Koubaa, M., Barba, F. J., Leong, S. Y., Khelfa, A., Greiner, R., \& Chemat, F. (2017). Extraction methods of essential oils from herbs and spices. In Essential Oils in Food Processing: Chemistry, Safety and Applications, 21-55.

Santos, R. P., \& Ferreira, L. C. (2017). Avaliação microbiológica do ambiente, utensílios, superfícies e das mãos dos manipuladores em uma unidade de abate de suínos na cidade de Januária-MG. Cad Ciênc Agr, 9(1), 44-48.

Saranya, S., Santhi, D., \& Kalaikannan, A. (2016). Ginger as a tenderizing agent for tough meats-A review. J. Livestock Sci, 7, 54-61.

Schaich, K. M. (2017). Rethinking lipid oxidation. In Food Lipids: Chemistry, Nutrition, and Biotechnology, Fourth Edition (pp. 479-497). CRC Press.

Shah, S. B., Parveen, Z., Bilal, M., Sartaj, L., Bibi, S., Nasir, A., \& Mahmood, A. (2018). Assessment of antimicrobial, antioxidant and cytotoxicity properties of Camellia sinensis L. Pak. J. Pharm. Sci., 31(4).

Sirocchi, V., Devlieghere, F., Peelman, N., Sagratini, G., Maggi, F., Vittori, S., \& Ragaert, P. (2017). Effect of Rosmarinus officinalis L. essential oil combined with different packaging conditions to extend the shelf life of refrigerated beef meat. Food chemistry, 221, 1069-1076.

Sohaib, M., Anjum, F. M., Arshad, M. S., \& Rahman, U. U. (2016). Postharvest intervention technologies for safety enhancement of meat and meat based products; a critical review. J. Food Sci. Technol., 53(1), 19-30.

Sousa, L. S., da Silva, Í. R. C., de Jesus Assis, D., da Cunha Pascoal, D. R., \& Druzian, J. I. (2013). Estudo prospectivo sobre as propriedades terapêuticas do Zingiber officinale (gengibre) com ênfase na ação antimicrobiana. Rev Geintec, 3(5), 427-436.

Suradi, K., Gumilar, J., Ladyani, G. M. L., \& Putri, N. S. W. (2019). The effect of duck meat marination with various concentrations of green tea extract (Camellia sinensis) on physical, microbiological and acceptability properties. Scientific Papers-Animal Science Series: Lucrări Ştiinţifice-Seria Zootehnie, 72, $137-142$.

Tanvir, E. M., Hossen, M., Hossain, M., Afroz, R., Gan, S. H., Khalil, M., \& Karim, N. (2017). Antioxidant properties of popular turmeric (Curcuma longa) varieties from Bangladesh. J. Food Qual., 2017.

Ulusoy, B., Hecer, C., Kaynarca, D., \& Berkan, Ş. (2018). Effect of oregano essential oil and aqueous oregano infusion application on microbiological properties of samarella (tsamarella), a traditional meat product of Cyprus. Foods, 7(4), 43.

Vergara, H., Cózar, A., \& Rubio, N. (2021). Lamb meat burgers shelf life: effect of the addition of different forms of rosemary (Rosmarinus Officinalis L.). CyTA-Journal of Food, 19(1), 606-613. 
Research, Society and Development, v. 10, n. 14, e10101421422, 2021

(CC BY 4.0) | ISSN 2525-3409 | DOI: http://dx.doi.org/10.33448/rsd-v10i14.21422

Vieira, S. A., Zhang, G., \& Decker, E. A. (2017). Biological implications of lipid oxidation products. J. Am. Oil Chem.' Soc., 94(3), 339-351.

Voloski, F. L. S., Tonello, L., Ramires, T., Reta, G. G., Dewes, C., Iglesias, M., ... \& Duval, E. H. (2016). Influence of cutting and deboning operations on the microbiological quality and shelf life of buffalo meat. Meat sci., 116, 207-212.

Witschi, H. P. (1986). Enhanced tumour development by butylated hydroxytoluene (BHT) in the liver, lung and gastro-intestinal tract. Food Chem. Toxicol., 24 (10), 1127-1130.

Wood, J. D. (2017). Meat composition and nutritional value. In Lawrie s Meat Science (pp. 635-659). Woodhead Publishing.

Yazgan, H., Burgut, A., Durmus, M., \& Kosker, A. R. (2020). The impacts of water and ethanolic extracts of propolis on vacuum packaged sardine fillets inoculated with Morganella psychrotolerans during chilly storage. J. Food Saf, 40(2), e12767.

Yoo, J., Lim, Y. M., Kim, H., Kim, E. J., Lee, D. H., Lee, B., ... \& Shim, I. (2018). Potentiation of sodium metabisulfite toxicity by propylene glycol in both in vitro and in vivo systems. Front. Pharmacol., 9, 161. 